\title{
A Critical Review of Value Chain for Irish Potato in Zimbabwe with Specific Regards to the Economic Policy: A Review
}

\author{
Nyasha Sakadzo ${ }^{1.2} \&$ Jeremiah Mavugara $^{2} \&$ Ashel Musara ${ }^{3}$ \\ ${ }^{1}$ Department of Soil and Plant Sciences. Faculty of Agriculture, Great Zimbabwe University, P.O. Box 1235, \\ Masvingo, Zimbabwe \\ ${ }^{2}$ Masvingo Christian College, P.O. Box 436, Masvingo, Zimbabwe \\ ${ }^{3}$ Near East University Food Engineering Department, Lefkosa, Turkish Republic of North Cyprus (TRNC) \\ Correspondence: Nyasha Sakadzo, Department of Soil and Plant Sciences. Faculty of Agriculture, Great \\ Zimbabwe University, P.O. Box 1235, Masvingo, Zimbabwe. Tel: 263-775-985-724. E-mail: \\ nsakadzo87@gmail.com
}

Received: June 5, 2020 Accepted: July 6, 2020 Online Published: July 16, 2020

\begin{abstract}
Potato production and consumption are booming worldwide, greater quantity of it is being processed into food and snacks. It is the most important horticultural crop which is a good substitute for maize to supplement carbohydrates. It was declared a national strategic food security crop on 18 May 2012 by the government of Zimbabwe. This paper critically review the value chain of Irish potato in Zimbabwe with a focus on its any government policy and support with regards to promoting the crop and key stakeholders involved in the value chain. The Irish potato value chain in Zimbabwe has great potential to improve and if well supported, it can contribute to the GDP of the country. This can be done if the government improve on its policy implementation through capacity development of its research and extension workers and more resources have to be availed to this area has showed great potential in terms of marketing and production. The key drivers at production level who will help in ensuring that necessary interventions are carried out to improve long term performance of the Irish potato value chain operate in an enabling environment. This is done by offering incentives to the potato farmers and all the value chain players. The economy of a country is driven by having well thought out policies and interventions that can even subsidies inputs and other raw material required along the value chain.
\end{abstract}

Keywords: Irish potato, Value chain, security, policy, GDP

\section{Introduction}

Irish potato (Solanum tuberosum L.) is considered to be a very important root and tuber crop in the world. It is considered to be the third important staple crop in the world as a source of carbohydrates after crops like wheat (Triticum aestivum) and maize (Zea mays) in Zimbabwe (Sakadzo et al., 2020; Masvodza, 2015; The herald, 2011). In 2008, the Food and Agricultural Organisation (FAO) declared the International Year of the Potato (Lutaladio et al., 2009).

Global agriculture policies and resources focus mainly on cash crops leaving Irish potato at the periphery. There is need for the world to readdress such bias as policy makers have to ensure that they create an environment that is conducive for support from both public and private investors. This support include among other factors breeding programs that improve the value chain. The world over, people and countries rely on wheat to make bread but if there are other alternatives means to make flour from potatoes it would help a lot. In West Africa, Guinea and Senegal have marginal Irish potato distribution networks where the dominant market is still local. The main challenge to exporting is the coming in of potatoes from Europe disturbing the local value chain (Lutaladio et al., 2009). Moreover, marketing of the crop in urban centers is affected by absence of storage facilities. As for the Sub Saharan region, there has been a notable increase in the size of area under potato production as most farmers in the area have responded to a high demand for fresh and processed potatoes. This increase in Irish potatoes and its products is being necessitated by an increase in urbanisation which has resulted in a change in food consumption patterns (FAO, 2008). Many fast foods outlets, takeaways and restaurants have caused an increase in demand for potatoes as its products are viewed as prestige food 
Therefore, there is limited information as the value chain of Zimbabwe potato industry is not yet clear and understood because the government has been focusing on maize as the staple crop (Svubure et al., 2017). The write up will critically review the value chain of Irish potato in Zimbabwe with a focus on its any government policy and support with regards to promoting the crop and key stakeholders involved in the value chain.

\section{Brief History of Irish Potato Introduction and Production in Zimbabwe}

The crop was introduced in Zimbabwe in the early $30^{\text {th }}$ century and common varieties grown include BP1, Amethyst, Mont Claire, Opal, Emerald and Jacaranda (Mpemba, 2016). In Zimbabwe, the crop is now the $3^{\text {rd }}$ most important source of carbohydrates after maize and wheat (The herald, 2011; Sakadzo et al., 2020). After realising the importance of Irish potato production, the Zimbabwean government boasted the industry when it introduced a policy that declared the crop a national strategic food security crop in 2012 (Svubure et al., 2017). The Zimbabwean climatic conditions allow potatoes to be grown throughout the year. This is mostly three times for short season varieties a factor that has attracted farmers as the crop production has proved to be a lucrative venture. However, fluctuation in demand on the market and crop rotation to control pests and diseases militates against growing the crop three times a year for small holder farmers (Fusire, 2001). Currently, area under potato cultivation is about 3500 hectares annually which produces an average of 20 tonnes per hectare (FAOSTAT, 2013; Sakadzo et al., 2020).

\section{Constraints to Potato Production}

The potato value chain face a lot of challenges such as shortage of improved quality seeds, low yield, low irrigation facility, poor disease control, perishability, lack of storage facility, poor post-harvest handling management, lack of processing facility, low skill and technology for processing, lack of facility, lack of capital and limited dishes/recipes. According to FAO (2008), the potato industry is being faced by a number of problems that include lack of diversity in potato varieties which reduces the ability to overcome problems of drought, diseases, pests, climate change and deceasing yields in marginal lands. The potato industry in Zimbabwe was largely dominated by whites who had commercial farms prior to the land reform programme. This land reform programme restructured the land tenure system of the country and introduced A1 and A2 models (Moyo, 2011). A1 model allocated small plots of about 6 ha to the poor and landless people in Zimbabwe for growing crops and grazing land whilst A2 models comprises of new black commercial farmers who were allocated about 35 ha self-contained plots (Svubure et al., 2017; Mkodzongi \& Lawrence, 2019).This programme resulted in many black people who became beneficiaries getting self-contained farm units ranging from 35-300ha depending on the area where one was allocated. It is these farmers who have started growing potatoes adding to the already existing commercial farmers (Svubure et al., 2015). So far Zimbabwe has an average potato yield of 20 tonnes per hectare but a lot of attention is paid to maize production. Masvodza (2015) and Sakadzo et al. (2020) pointed out that lack of knowledge on time of earthing up and cultivation methods and cost of production are major factors affecting potato production in Zimbabwe. This is because maize is the staple crop but there should be a policy which enables the focusing of other alternative sources of starch like potatoes (Mpemba, 2016). The government of Zimbabwe has analysed Irish potato production systems which provided an insight into the different stakeholders involved which include existing grower categories, natural resource base, input use, average yield, required and available infrastructure, production constraints and any solution (Manzira, 2011). There has been few authors who have looked at the value chain for Irish potato in Zimbabwe with specific regards to the economic policy. Therefore, there is limited information as the value chain of Zimbabwe potato industry is not yet clear and understood because the government has been focusing on maize as the staple crop (Svubure et al., 2017).

\section{Importance of Potato Value Chain}

According to Kaplinsky and Morris (2001), a value chain is defined as a wide range of actions, set activities and actions that are required or performed to bring a product from the start through production until it gets to the final consumer and then disposed after use. In any value chain the most valuable aspect is the economic value addition or any loss incurred by chain actors at different linkages in the chain and the sum value involved in the whole chain (Gelli et al., 2015). Stakeholders involved include input suppliers, producers, processors and markets. There is need to have technical, financial and business service providers that supports the value chain. Moreover, there has to be regulation from the local and national government which provide an environment where the chain is embedded (Kula et al., 2006). Globalisation and the rise of international trade are part of the value chain environment (Figuiredo Jr et al., 2014).

The world over, value chain development can be used by governments in policy formulation especially on policies that help collaboration among value chain actors (Humphrey and Memedevic, 2006). Gelli et al, (2015) has noted that the demand for value added food and food safety standards has aroused a special interest in food value chain 
development. The prevalent of malnourishment related diseases has resulted in more funds being channelled towards potato value chain interventions with an emphasis on nutrition. The crop contains effective antioxidants like carotenoids and phenols which according to Donnelly and Kabow (2011) prevent diseases like diabetes and a serving of potato a day provide $30-48 \%$ of the recommended daily intake of macro minerals. This in a way show the importance of Irish potatoes in the human diet as its nutritional value are a clear testimony that it can contribute to the country's food security. The potato industry allows people to earn as it comprises of a long chain of individuals who specialises in selling seed, farmers, farm workers, marketers and the consumer which enable the industry to contribute to the GDP of Zimbabwe. This is because the country's economy is agro based and the agricultural sector has realised that there can be increased income for farmers and other stakeholders along the value chain (Hawkes and Ruel, 2011). If there are proper support structures in terms of government policies, the Irish potato supply chain can provide opportunities that promote nutrition and health as a result of readily available quality and affordable food for everyone. However, Zimbabwe seems not to have a properly documented Irish potato industry as the government and the majority of black farmers see the crop as capital intensive.

\section{Stakeholders Involved in Value Chain of Irish Potatoes}

In promoting Irish potato production and value chain, there is need to be familiar with the stakeholders involved in the potato industry (Svubure, 2015). The key stakeholders in a value chain of Irish potatoes are involved in production (farmers), distribution, wholesaling, processing, retailing, service provision and household use. To be more specific, these key stakeholders include seed potato growers, the farmers, distributors (traders), transporters, processors and these include hotels, restaurants, fast food outlets, urban fruit and vegetable markets, wholesalers, retail supermarket chains, household consumers and service providers, (Svubure et al., 2017). There are also other stakeholders who include the government especially the line Ministry of Agriculture, Lands and Rural Resettlements, other government agencies which provide technical and extension services, the Crop Breeding Institute and private institutions. The Zimbabwean Irish potato value chain is complex as the pathway involved from production to end use has multiple stakeholders which operates in a socio economic and political environment. In terms of production according to Svubure et al., (2017), 88\% of the produce is for consumption with the remaining $12 \%$ used for seed and regeneration purposes. The Zimbabwe climate allows farmers to grow Irish potatoes all year round especially in areas where they have access to irrigation that allows the farmers to supplement rainfall during the dry season (Svubure, 2015). This is unlike in other countries like in the Kenyan value chain which has only two main cropping season where storage facilities are a necessity. The absence of storage facilities in the Zimbabwean value chain imply that there is no added cost to the supply chain and also there is absence of the risk of crop loss due to diseases. The Mozambique government has a major problem in terms of having insufficient storage facilities (FAO, 2009).

The Zimbabwean government has also showed its support to the Irish potato industry as it banned the importation of cheap imports in 2010. This was a big boost to the local farmers as it protected them against cheap South African produce. More so, the government in 2012 declared Irish potato a national strategic food security crop (Herald, 2012). This was done through a government policy which enabled all Irish potato farmers to get government support through the different agricultural programmes (Mpemba, 2016). In a way to avoid rampant production of seeds that lead to pest and disease spread, the Zimbabwean government's Seed Services Institute oversee the seed certification of all seeds in the country. This functional seed certification system get its mandate from the Seeds Act (Chapter 19:13) of 1971 with an enabling regulation of the Seeds Regulation (1971) and Seeds certification Scheme Notice (2000). This has enabled the potato sector not to recycle seeds from uncertified material as it leads to loss of genetic vigour as in the case of Mozambique where the certified seeds production satisfies $4 \%$ of national seed requirements. The balance is met by uncertified material with more dependence on imported seed. According to Hirpa et al., (2010), countries like Ethiopia have a poor seed production system which has affected the value chain where there are low yielding varieties produced which are susceptible to diseases.

The potato sector depends on supplementary irrigation more than maize crop. Therefore, there is need to invest in functional irrigation infrastructure as the crop is grown all year round in Zimbabwe. Janssen et al. (2013) posits that the majority of potato farmers in Kenya have a limited off season production as they have few farming areas with access to irrigation facilities. This obviously makes the farmers to depend on rain fed production. This is where the law of supply and demand comes in where during the rainy season, the supply of potatoes will be high as most farmers will have grown the crop. The prices of potatoes during the off season is higher than during the rainy season as demand for the crop will be higher than supply (Janssen et al., 2013). In Zimbabwe since the potato production industry occurs throughout the year, production will be even making high price fluctuations uncommon It is only recently when the government introduced bond notes where there has been price distortions but as from 2009 when the government of Zimbabwe adopted the US\$ as the trading currency the commodity prices have been 
stable. There have been high cost of production recorded in the A2 farmers than A1 farmers per hectare with seed and fertiliser being the most expensive inputs. Potato growers in Zimbabwe experience low yields although they use high levels of synthetic fertilisers and chemicals to control pests and diseases (Svubure et al., 2015). In order to realise better returns, farmers can use organic manure from compost or use high yielding varieties which in a way will help consumers to afford the produce. The Zimbabwean supply chain is adversely affected by high production costs coupled with poor road network which increases the transport costs and also it reduces the potato quality during transit. The Zimbabwean government after the land reform programme failed to give its newly resettled farmers title deed that could have been used to access lines of credit from banks and other credit providers. They were just given 99 year leases which cannot be used as collateral against a loan. This affects the performance of the potato value chain in Zimbabwe so there is need for modern machinery and other farming equipment that might be of use during production.

\section{Value Added Activities of Potato Stakeholders}

a) Research and development

Produce codified knowledge on new varieties, pests, weeds and disease management strategies. In Zimbabwe, we have the Department of Research and Specialist services (DRSS) so as the Plant and Crop Protection Unit (PCPU). They are involve in new product development or culinary uses.

b) Input suppliers

These include private companies and government agencies such as command agriculture. They provide inputs such as seed, fertilisers and pesticides for potato growers there by promoting potato value chain. Potato farmers in Zimbabwe obtain their seed from different sources which sometimes is noncertified. Seed certification ensures provision of disease free seed to growers. Some use their own seed. Potato growers obtain fertiliser and biocides from private companies such as Zimbabwe fertiliser company (ZFC).

c) Potato producers

This is one of the major potato value chain actors following input suppliers. They produce potatoes. A1, A2, communal and large scale commercial growers are prevalent in Zimbabwe. Potato production in Zimbabwe is most done under irrigation whilst limited production is based on rain-fed system. Potato growers they harvest and do post-harvest technology such as: sorting, grading, packing, transporting, loading and unloading potatoes. They also separate damaged and undamaged tubers. Damaged and bruised potatoes are consumed at household level. The farmers select medium and large potatoes for immediate sale and small ones are kept for seed.

d) Traders/Brokers

They play a significant role in potato marketing system of Zimbabwe. They facilitate potato truncation by linking producers with traders, wholesaler with another wholesalers so as retailers. The brokers may go beyond by controlling and fixing prices in an informal way.

e) Wholesale distributors

These include Mbare musika who distribute to chain supermarkets, small supermarkets, food restaurant, hotel, fast foods outlets etc. This is one of the most economically important value chain actors who determine return per capita for most potato growers.

f) Food processors

Potatoes are mostly consumed in boiled form and cooked in meals. Currently, potato chips, crisps and roasted potatoes are becoming common especially in towns in Zimbabwe. In urban areas some people usually consume potatoes mixed with other vegetables. Potato processors usually prefer large sized potato for processing. Processed potato products such as snacks and chips have become a centre of attraction in many supermarkets selling these products. They play an invaluable role in value addition by being involved in the processing of potato products such as snacks etc. This is facilitated by food engineers.

g) Potato retailers

These are also actors in potato value chain in Zimbabwe. They stand as the last link between producers and consumers. Sometimes they buy potatoes directly from producers. Retailers usually offer according to requirement and purchasing power of the buyers

h) Potato consumers 
Potato consumers influence economic capita gain or loss in the potato value chain. They are influencing actors in potato value chain In Zimbabwe. They include: households, restaurants, cafes and institutions such as higher education institutions, universities, colleges, etc. Capita consumption of potato at these institutions may also undergo a slack with respect to supply and demand may increase as students' cafeteria will be high.

i) Potato service providers

Agricultural Rural Extension Officers (AREX) provide extension services by transmitting knowledge to farmers on potato production and management requirements. Tobacco Research Board (TRB) is involved in assisting farmers on management of common pests and diseases of solanaceous plants as some farmers involved in tobacco farming are into potato production. Non-Governmental Organisations are also involved in value addition by partnering in the value chain so as to ensure food security.

j. Food quality controllers (FQCs)

They play a pivotal role between a farmer and the wholesale. In this era, the FQCs do the grading of potatoes. They also check for the level of biocides, insecticides and general chemicals in the potato plant if they are below the threshold to prevent food poisoning.

\section{Effects of the Socio-Economic and Political Environment on Potato Value Chain in Zimbabwe}

Of great importance is to note that for any crop value chain to succeed, the socio-economic and political environment must be conducive enough to promote investments and improvement in the value chain. Zimbabwe has also been affected by rampant and want on corruption which is immensely affecting the value chain as cases of smuggling of potatoes from South Africa are on the rise. These cheap imports are a threat to the pricing of the local potatoes as they tend to attract consumers who are facing economic challenges. Production of seed tubers in Zimbabwe is limited by strict production agronomy that prevents spread of viral diseases through vegetative propagative material like tubers. Haverkort et al. (2015) argues that, there is need to release new potato varieties in the market that address different needs of farmers and the consumers at large. This will help to out compete the cheap imports from South Africa that tend to affect the Zimbabwean value chain.

Zimbabwe potato value chain is affected by socio economic factors and the political environment that have a bearing on the policies related to agriculture. The socioeconomic factors currently being experienced in Zimbabwe was triggered by the emergence of the bond note which is being rated at interbank rate with American United States dollar. Like the issue of bond notes when they were issued on the market they were 1:1 but today the rate has gone beyond reach. Farmers are business people, they also need a well stable economy as a constant motivator. No sane person can go into the fields to produce a non-profiting product. There is absolutely lack of motivation from our government side. Policy inconsistency is what gave birth to the smuggling of cheap potatoes hence demotivating our farmers. The potato value chain is significantly being affected as US\$ cannot be formally accessed by most growers in banks so as to plough back the profits. Informal marketing is currently adding more to the potato value chain. There is higher rate of inflation which In Tanzania, the value chain only involve farmers and their inputs who are not categorised as in Zimbabwe where there are A1 and A2 model farmers. Some of these $\mathrm{A} 1$ and $\mathrm{A} 2$ farmers who obtained land during the land reform program have deceased from potato production. This has significantly affected the potato value chain in Zimbabwe. There is need for the government of Zimbabwe to make an audit so that the land where potatoes were grown is revived again.

The Irish potato value chain in Zimbabwe has great potential to improve and if well supported, it can contribute to the GDP of the country. This can be done if the government improve on its policy implementation through capacity development of its research and extension workers and more resources have to be availed to this area has showed great potential in terms of marketing and production. The key drivers at production level who will help in ensuring that necessary interventions are carried out to improve long term performance of the Irish potato value chain operate in an enabling environment. This is done by offering incentives to the potato farmers and all the value chain players. The economy of a country is driven by having well thought out policies and interventions that can even subsidise inputs and other raw material required along the value chain.

\section{Conclusion}

The value chain of Irish potatoes is affected by socio economic factors and the political environment that have a bearing on the policies related to agriculture. Zimbabwe has also been affected by rampant and want on corruption which is immensely affecting the value chain as cases of smuggling of potatoes from South Africa are on the rise. These cheap imports are a threat to the pricing of the local potatoes as they tend to attract consumers who are facing economic challenges. Production of seed tubers in Zimbabwe is limited by strict production agronomy that prevents spread of viral diseases through vegetative propagative material like tubers. 


\section{Recommendations}

There is need for more resources to be channeled towards Irish potato production as it has shown to help in addressing food security. In order for all the stakeholders to financially benefit, there is need for the government to put policies that promote value addition as selling a complete product is more profitable than selling raw materials. Private companies and governments should introduce potato processing facilities. Input provision should be adequately scheduled to meet the calendar of irrigated crop such as potato. Health agents and Extension officers should be capacitated so as to raise awareness campaigns on potato food value and processing techniques to improve consumption in urban centers. There is also need for local seed production so as to reduce transportation. The Potato industry should create a value chain forum so as to bring various stakeholders so as to solve challenges being faced in potato value chain. Emphasize to policy makers the income equity food security aspects of potato farming and its potential in achieving Millennium Development Goals. There is need to engage policy makers at local, national and regional level in preparing potato development plans and policies that encourage potato consumption and production

\section{References}

Brown, C. R. (2005). Antioxidants in Potato. American Journal of Potato Research, 82. Springer International Publishing. https://doi.org/10.1007/BF02853654

Donnely, D. J., \& Kobow, S. (2011). Role of Potatoes in Human Health. Plant science Dept \& School of Diabetics and Human Nutrition, McGill University, Motreal.

Emana, B., \& Nigussie, M. (2011). Potato Value Chain, Analysis and development in Ethiopia: Case of Tigray and SNNP Regions. International Potato Centre (CIP-Ethiopia).

Figueredo, H. S. Jnr., Meuwissen, M. P. M., \& Oude Lansink, A. G. J. M. (2014). Integrating Structure, Conduct and Perfomance into Value Chain Analysis. Journal on Chain and Network Science.

Food and Agriculture Organisation (FAO). (2009). State of Plant Genetic Resources for Food and Agriculture in Zimbabwe. A Country Report (1996-2008). Department of Agricultural Research for Development, Ministry of Agriculture, Mechanization and Irrigation Development

Food and Agriculture Organization of the United Nations Statistics Division (FAOSTAT). (2013). Retrieved 7 October 7, 2014, from http://faostat3.fao.org

Gelli, A., Hawkes, C., \& Donovan, J. (2015). Value Chains and Nutrition: A Framework to Support the Identification, design and Evaluation of Interventions. International Food Policy Research Institute (IFPRI). https://doi.org/10.2139/ssrn.2564541

Haverkortc, A. J., Steyn, J. M., Svubure, O., \& Struik, P. C. (2015). Yield gap analysis and resource footprints of Irish potato production systems in Zimbabwe. Field Crops Research, 178, 77-90. https://doi.org/10.1016/j.fcr.2015.04.002

Hawkes, C., \& Ruel, M. (2011). Value Chains for Nutrition. Prepared for the International Food Policy Research Institution.

Hirpa, A., Meuwissen, M. P. M., \& Tesfaye, A. (2010). Analysis of Seed Potato Systems in Ethiopia. Am J. Pot Res 87. https://doi.org/10.1007/s12230-010-9164-1

Janssens, S. R. M., Wiersema, S. G., \& Gross, H. (2013). The Value Chain for Seed and Ware Potatoes in Kenya: opportunities for development.

Kaplinsky, R., \& Morris, M. (2001). A handbook for Value Chain Research. Prepared for International development Research Centre (IDRC). https://doi.org/10.3362/0957-1329.2006.017

Khurana. M. S. (2006). Handbook of Potato Production, Improvement, and Postharvest. Harworth Press. ISBN 978-1-56022-272-9.

Kula, O., Downing, J., \& Field, M. (2006). Value Chain Programmes to Integrate Competitiveness; Economic Growth and Poverty Reduction. Small Enterprise development.

Li, P.H ed. (1985). Potato physiology, Academic press Inc. London.

Lutaladio, N., Ortize, O., Haverkort, A., \& Caldize, D. (2009). Sustainable Potato Production. Guidelines for developing countries. International year of the potato. FAO.

Manzira, S. (2011). Potato Production Hand book, Harare Zimbabwe: Potato Seed Association

Martin, J. H., Stamp. D. L., \& Waldren, R. P. (2006). Principles of Field Crop production 4th Edition. Pearson 
Education Inc., Upper Suddle River, New Jersey.

Masvodza, R. (2015). Feasibility of Sack Potato Production as a New Technique used in Some Urban Parts of Zimbabwe. Journal of Agriculture and Ecology Research International, 3, 201-208. https://doi.org/10.9734/JAERI/2015/13700

Mkodzongi, G., \& Lawrence, P. (2019). The fast-track land reform and agrarian change in Zimbabwe. Review of African Political Economy, 46, 159, 1-13. https://doi.org/10.1080/03056244.2019.1622210

Moyo, S. (2011). Three Decades of Land Reform In Zimbabwe. Journal for Peasant Studies, 38(3). https://doi.org/10.1080/03066150.2011.583642

Mpemba, T. R. (2016). Evaluation of new Irish Potato (Solanum tuberosum L.) Varieties for Yield Potential in Zimbabwe. Department of Agronomy Faculty of Natural resources Management and Agriculture Midlands State University, Zimbabwe.

Nyagaka, D. O., Obeve, G. A., \& Nguyo, W. (2009). Economic Efficiency of Smallholder. Irish Potato Producers in Kenya: A case of Nyandama North District. Department of agriculture Economics and Agribusiness Management, Egerton. Kenya.

Sakadzo, N., Makaza, K., \& Tafirenyika, F. (2019). Effects of time of earthing up on yield and yield parameters of Irish potato (Solanum tuberosum L.) in Zaka District, Zimbabwe. Agricultural Science, 1(1), 39-46. https://doi.org/10.30560/as.v1n1p39

Seed Act [Chapter 19:3] (1971). Print Flow Government Printers, Harare: Seed Act.

Seeds Certification Scheme Notice. (2000). Print Flow Government Printers, Harare: seeds Certification Scheme Notice.

Svubure, O., Struik, P. C., Haverkort, A. J., \& Steyn, J. M. (2017). Analysis of the Potato (Solanum tuberosum) Value Chain in Zimbabwe. Outlook on Agriculture Journal, 46(1), 49-46. https://doi.org/10.1177/0030727017690655

Svubure, O., Struik, P. C., Haverkort, A. J., \& Steyn, J. M. (2015). Yield Gap Analysis and Resource Footprints of Irish Potato Production Systems in Zimbabwe. -https://doi.org/10.1016/j.fcr.2015.04.002

Svubure, O. (2015). Agronomic and Environmental Studies of Potato (Solanum tuberosum L.) and analysis of its value chain in Zimbabwe. Wageningen University, Wageningen.

The Herald. (2011). October. High Costs of Production Frustrate Seed Potato Farmers, The Herald, Harare, Zimbabwe.

The Herald. (2012). May. Potato Declared Strategic Security Food Crop, The Herald, Harare, Zimbabwe.

\section{Copyrights}

Copyright for this article is retained by the author(s), with first publication rights granted to the journal.

This is an open-access article distributed under the terms and conditions of the Creative Commons Attribution license (http://creativecommons.org/licenses/by/4.0/). 